\title{
Did God Answer That Prayer?
}

\section{Spiritual Perception and the Epistemology of Petitionary Prayer}

\author{
Christopher G. Woznicki | ORCID: 0000-0002-5249-735X \\ Fuller Theological Seminary, Pasadena, California, USA \\ christopherwoznicki@fuller.edu
}

\begin{abstract}
In his recent book Petitionary Prayer, Scott Davison presents an epistemological challenge to petitionary prayer. He asks: If $\mathrm{S}$ prays for God to bring about event $\mathrm{E}$, and $\mathrm{E}$ in fact occurs, how could one be justified in believing that $\mathrm{E}$ was an answer to S's prayer? Apart from direct revelation in which God explicitly provides reasons for believing that E was an answer to prayer, Davison argues, S could not know that S's prayer had been answered by God. Thus, the person praying should remain agnostic about answered prayers. I argue that in failing to attend to two theological resources available in the Christian tradition - the concept of spiritual senses and teachings about the relational nature of prayer-Davison's conclusion is premature. Drawing upon recent literature on the epistemology of perception and the theology of prayer, I argue that one can be confident that God has answered one's prayers.
\end{abstract}

\section{Keywords}

epistemology - perception - petitionary prayer - principle of credulity - spiritual senses

With the onset of the coviD-19 pandemic it is undoubtedly the case that some Christians will pray that God would heal their loved ones who are afflicted by the virus. In some cases, believers will pray for God to heal their loved ones through ordinary means, for example, wise doctors, potent medicines, and so forth. In other cases, believers will pray for miraculous healings. Some of those who have been prayed for will recover from the disease; tragically, others will not. Some Christians will believe that the recovery of those who have 
been sick ought to be attributed to God answering their prayers, but is such a belief justified?

In a recent book titled Petitionary Prayer: A Philosophical Investigation, Scott Davison presents an epistemological challenge to petitionary prayer. He wonders, "If someone prays for God to bring about some event, and the event in fact occurs, what justifies believing that the event was the answer to that person's prayer?" Apart from direct revelation in which God explicitly provides reasons for believing that the event was an answer to prayer, Davison argues, one could not know that the prayer has been answered by God. To illustrate this point, consider praying for one's grandparent to be healed from CoviD-19. According to Davison, even if Grandpa recovers from the virus, apart from divine revelation, one cannot know that God has healed Grandpa. Typically, Davison explains, humans do not have access to direct revelation about explanations of events-such as a healing - so the reasonable thing to do, he claims, is to withhold belief about whether or not some event — such as a healing — is answer to prayer. If Davison's reasoning is correct, then much of what Christians tend to believe about prayer seems to be undermined. Consider, for example, the space given to testimonies during traditional pentecostal services; this time in the service is dedicated to giving space to people to testify about how God has acted in their lives. ${ }^{1}$ Quite often these testimonies involve descriptions of answered prayer requests, such as prayers for healing. Even apart from the pentecostal tradition, in traditional evangelical small groups or Bible studies one is likely to hear someone share a story of how God answered their petitions about such things as a job interview, their nephew's mental health, or for their aunt's battle with cancer. ${ }^{2}$ If Davison is correct, then these Christians ought to withhold belief about whether or not God has answered their prayers. This consequence seems to undermine the experience of many — if not most—Christians that sometimes we ought to believe that God has in fact answered our prayers.

In this essay I argue that in failing to attend to two theological resources available in the Christian tradition - the concept of spiritual senses and teachings about the nature of prayer-Davison's conclusion, that the belief that the

1 Arlene M. Sanchez Walsh, "Pentecostals," in Handbook of Latina/o Theologies, ed. E.D. Aponte and M.A. De La Torre (St. Louis: Chalice Press, 2006), 199. For a sample order of service, see Mark J. Cartledge, Testimony in the Spirit:Rescripting Ordinary Pentecostal Theology (Farnham: Ashgate, 2010), 195 .

2 For further context regarding pentecostal/charismatic understandings of the role of those involved in praying for healing and holistic approaches, see, for example, the chapter titled "Spiritual Empowerment: Pray-ers, Prophets, and Healers in the Pew" by Margaret Poloma and John C. Green, The Assemblies of God: Godly Love and the Revitalization of American Pentecostalism (New York: New York University Press, 2010), 121-143. 
coming about of some event was an answer to prayer is unjustified, is actually premature. Attending to these resources allows us to provide warrant for believing that God answered a petitionary prayer without needing to appeal to direct revelation.

My argument proceeds as follows. In section one I present Davison's argument for why one ought to withhold belief regarding answered prayers. In section two I introduce the concept of spiritual senses, specifically spiritual perception, as a way to provide warrant for believing that God has answered some prayers. Discussion of spiritual perception necessarily leads us to the topic of the epistemology of spiritual senses. I argue that, based on the principle of credulity, one ought to treat spiritual perceptions as credible unless one has overwhelming reasons to do otherwise. In section three I shift my attention to the theology of petitionary prayer. Given a Christian theology of petitionary prayer, the probability that one's spiritual perception of answered prayers is correct is enhanced. I conclude by briefly discussing the pastoral ramifications of believing that our beliefs about answered prayers are warranted.

Davison's Epistemological Challenge to Petitionary Prayer

Can I be justified in believing that God has answered some particular petitionary prayer that I offered to him? This is a question of utmost pastoral significance. It is also the question that preoccupies Davison in his chapter on epistemological challenges to prayer. Davison believes that theoretically one could answer the question affirmatively: "It seems theoretically possible that God could reveal directly to someone that a specific petitionary prayer has been answered." ${ }^{3}$ God might speak from a burning bush, provide a dream, address someone in an audible voice, or use some other way to tell an individual directly that he has answered their prayer. Yet, Davison believes that "it is very unusual for people to claim that God has provided it [direct revelation] and the teachings of the central theistic religious traditions do not lead us to expect it today."

3 Scott Davison, Petitionary Prayer: A Philosophical Investigation (New York: Oxford University Press, 2017), 63.

4 Todd M. Johnson and Gina A. Zurlo, World Christian Encyclopedia, 3rd ed. (Edinburgh: Edinburgh University Press, 2020), 6-8. Douglas Jacobsen, in his forthcoming The World's Christians, 2nd ed., classifies pentecostal/charismatic movements into three categories: Pentecostals proper, charismatic Christians, and a pentecostal penumbra. See Jacobsen, The World's Christians: Who They Are, Where They Are, and How they God There, and ed. (Chichester, UK: Wiley/Blackwell, 2020). See also Nimi Wariboko and L. William Oliverio, Jr., "The Society for Pentecostal Studies at 50 Years" Pneuma 42 (2020): 327-330. 
By my lights this claim ignores a vast swath of what Pentecostals might have to say regarding direct revelation. ${ }^{5}$ The fact that as of the year 2020 there are an estimated 644 million "Pentecostals/Charismatics" worldwide—roughly 8.3 percent of the world's population - makes it a "central theistic religious tradition." ${ }^{16}$ According to numerous Pentecostals, God quite often speaks directly to believers; it is often taught that one should expect God to speak directly to those who seek his voice. ${ }^{7}$ But for the sake of argument let us say that Davison is right and that God does not directly speak to believers about the specific actions he takes in their lives. Apart from direct divine revelation, if person $S$ prays for event $\mathrm{E}$ to occur, and $\mathrm{E}$ occurs, how can $\mathrm{S}$ be justified in believing that $\mathrm{E}$ was an answer to S's prayer? It appears that the coming about of $E$ could be explained in numerous ways:

(1) E was caused by natural forces.

(2) E was caused by some intelligent person who is not God.

(3) God brought about E because someone else prayed for it.

(4) God brought about $\mathrm{E}$ because $\mathrm{S}$ prayed for it.

In scenarios (1)-(3), the coming about of E was not, in fact, an answer to S's prayer. ${ }^{8}$ How might $S$ be warranted in believing (4)? Perhaps $S$ observes a cor-

5 The possibility of direct revelation is not limited to Pentecostals. Roman Catholics and Orthodox Christians sometimes make similar claims about the possibility of this phenomenon, though pentecostal/charismatic Christians are often well known for making this type of claim.

6 William Kay, Pentecostalism (London: SCM, 2009), 12.

7 Matthias Wenk, "Spiritual Gifts: Manifestations of the Kingdom of God," in The Routledge Handbook of Pentecostal Theology, ed. Wolfgang Vondey (London: Routledge, 2020), 305-306. Josh Samuel, The Holy Spirit in Worship Music, Preaching, and the Altar: Renewing Pentecostal Worship (Cleveland: CPT Press, 2018), 1. See also Tanya Luhrmann, When God Talks Back: Understanding the American Evangelical Relationship with God (New York: Alfred A. Knopf, 2012), 39-71. The notion that God can directly communicate, through personal revelation, to a person does not necessarily mean that God does not use secondary causes to communicate; God is free to do so. In such a case, I would still consider the communication to be direct revelation.

8 A concurrentist would argue that in some sense God is a cause of every event that occurs, so in some sense God is also a cause of (1) and (2). God could use (1) or (2) to answer the prayer. Yet, in the scenario I am describing above, this form of primary causation, as opposed to secondary causation, is not equivalent to saying that God answered the prayer with (1) or (2) as secondary causes. It should be added that God often uses secondary causes in order to answer prayer; God is not always the immediate or proximate cause.

The issue of God answering prayer raises the matter of God's sovereignty. God is sovereign and could act differently given the pray-er's request. Prayer, as Vincent Brümmer notes, is not magic. Prayer "is not a sufficient condition make it inevitable for God to comply with the request. In that case prayer would become a kind of magical technique by which God could be 
relation between the events. S offered a prayer for E, subsequently E occurred. For example, Mary prays for her sick husband, Peter, to recover from covid19, and immediately after her prayer Peter feels much better; he gets tested and the results show that he no longer has CoviD-19. By the lights of many people of faith it would seem obvious that God answered the prayer. But can Mary truly rule out explanations (1)-(3)? Might some natural anti-virus, unknown to scientists, have entered Peter's body at precisely the moment Mary prayed, destroying the virus in Peter's body? Perhaps some supernatural agent, such as an angel, destroyed the virus afflicting Peter. Maybe Peter's friend, Felicia, prayed for Peter to be healed and God responded to Felicia's prayer instead of Mary's. If Mary cannot distinguish which of these scenarios took place, it seems difficult to say that Mary knows that God answered her prayer. Is there a way for Mary to justifiably rule out (1)-(3)? Davison insists that she cannot. In order to affirm (4), Mary would need to possess information that God specifically was responding to her request. Apart from God telling her, Mary cannot possess such information. Mary might correctly believe (4) but she is not warranted in holding (4) unless God has revealed (4) to her. Given this scenario, Davison says that the most reasonable thing for someone like Mary to do in this case is to withhold belief as to whether or not Peter's recovery was an answer to her prayer. How come? Davison operates with the principle that, "If a person cannot distinguish which of two (or more) possible and incompatible explanations of the occurrence of some event $E$ is operative, then $S$ does not know that one of the explanations is operative, even if $S$ believes this and it is true." ${ }^{\prime 9}$ Let us call this "Davison's Discernment Principle" (DDP). Given DDP, Davison concludes that in cases where God does not reveal that he has answered a prayer, "the most reasonable thing for $S$ to do here would be to withhold belief on the question of whether or not the occurrence of $E$ was an answer to S's petitionary prayer."10 Let us assume that Davison's principle is correct, that if one $S$ cannot discern between explanations for $E$, then $\mathrm{S}$ cannot know that $\mathrm{E}$ is an answer to S's prayer. Even if we assume DDP is correct, we might rightly question whether DDP always applies when people offer petitionary prayers. According to Christian tradition it may be possible to perceive God's actions; if such perceptions are warranted, then perhaps S's belief in (4) would be warranted since S did not arrive at a belief in (4) through a process of discerning (4). Additionally, Christian teaching on the

manipulated by us." Brümmer, What Are We Doing When We Pray (London: scm Press, 1984), 33-34.

9 Davison, Petitionary Prayer, 68.

10 Davison, Petitionary Prayer, 68. 
nature of prayer provides reasons for $S$ to believe that $E$ was an answer to prayer. If this is right, then $S$ may be warranted in believing that $\mathrm{E}$ was an answer to prayer. These two sets of resources, which Christians could avail themselves of, ought to push Christians to deny Davison's call to withhold belief about whether or not God answered a specific prayer. Let us examine each in turn.

There are teachings about spirituality that run across diverse Christian traditions. One such teaching often goes by the term "spiritual senses." According to this teaching it is possible to perceive God and his actions in a manner that is, mysteriously, akin to our other perceptions. ${ }^{11}$ Accordingly, the spiritual senses are in some way analogous to our physical senses. Believers are said to "taste and see" the goodness of the Lord, "hear" the word of the Lord, and smell the "aroma" of Christ. ${ }^{2}$ In his now famous essay on the topic, "Le début d'une doctrine des cinq sens spirituels chez Origèn," Karl Rahner wrote that spiritual senses are not to be thought of as being merely metaphorical; they are literal expressions of a way of perceiving that are analogous to the five physical senses (touch, sight, hearing, smell, and taste). ${ }^{13}$ The five physical and five spiritual senses are two different sets of powers that aid in the perception of the physical and spiritual world. Sarah Coakley and Paul Gavirlyuk rightly object to Rahner's scheme, saying that "Rahner's definition of what must count as a proper doctrine of spiritual perception is unduly restrictive." ${ }^{14}$ While Christians have written about spiritual senses that are analogous to the five physical senses, Rahner was too quick to label such Christian teaching a "doctrine of five spiritual senses." First, it is not evident that there is such a "doctrine," second, it is not clear that the spiritual exemplars of the past used the fivefold scheme. ${ }^{15} \mathrm{In}$

11 Any theological discussion about perception, whether it be physical perception or spiritual perception must acknowledge the noetic effects of sin. Perception, given the effects of having a fallen nature, does not always function properly and needs to be restored by the Spirit through a sanctifying process.

12 See, for example: Psalm 34:9; Isaiah 1:10, and 2 Corinthians 2:15.

13 Karl Rahner, "Le début d'une doctrine des cinq sense spirituels chez Origène," Revue d'Ascétique et de Mystique 12 (1932): 114.

14 Paul L. Gavrilyuk and Sarah Coakley, "Introduction," in The Spiritual Senses: Perceiving God in Western Christianity, ed. Paul Gavrilyuk and Sarah Coakley (Cambridge: Cambridge University Press, 2012), 5 .

15 Gavrilyuk and Coakley, "Introduction," 5. 
contrast to Rahner's rather restrictive doctrine, Coakley and Gavirlyuk offer the following definition of spiritual senses:

"Spiritual senses" is an umbrella term covering a variety of overlapping, yet distinct expressions in which "sense" in general or a particular sensory modality (vision, audition, olfaction, touch or taste) is typically qualified by reference to the spirit ... heart ... soul ... mind or intellect ... inner [man] ... or faith. ${ }^{16}$

These distinct expressions are supposed to capture the notion that the word "spiritual" before "senses" is meant to indicate nonphysical modes of perception. This definition, I take it, is minimalist enough to capture the manifold ways in which spiritual senses appear in the Christian tradition.

\subsection{Richard Swinburne on Spiritual Perceptions}

In his classic defense of theism, The Existence of God, Richard Swinburne offers a contemporary analysis of spiritual perception. He distinguishes among five types of spiritual perceptions. The first type consists of experiences of God or his actions where some agent perceives God or his actions in perceiving "a perfectly ordinary non-religious object."17 The paradigm example of this is someone perceiving some physical object, such as El Capitan at Yosemite or the Grand Canyon, as God's handiwork. Consider, as another example, Jonathan Edwards's description of how he saw ordinary objects in creation:

God's excellency, his wisdom, his purity and love, seemed to appear in everything; in the sun, moon and stars; in the clouds, and blue sky; in the grass, flowers, trees; in the water, and all of nature ... I often used to sit and view the moon for a long time; and so in the day time, spent much time viewing the clouds and the sky, to behold the sweet glory of God in these things. ${ }^{18}$

The second type of spiritual perception consists of "experiences that people have in perceiving very unusual public objects."19 The apostle Paul's experience

\footnotetext{
16 Gavrilyuk and Coakley, "Introduction," 5.

17 Richard Swinburne, The Existence of God, 2nd ed. (Oxford: Oxford University Press, 2004), 299 .

18 Jonathan Edwards, Letters and Personal Writings, vol. 16, The Works of Jonathan Edwards, ed. George Claghorn (New Haven: Yale University Press, 1998), 793-794.

19 Swinburne, The Existence of God, 299.
} 
on the road to Damascus fits into this category. The third type consists of "cases where the subject has a religious experience in having certain sensations private to himself, sensations of a kind describable by normal vocabulary used for describing the sensations that result from the use of our five senses." ${ }^{20}$ Joseph dreamed that he saw an angel, Moses heard a voice speaking from a burning bush, Ezekiel—presumably — tasted the scroll that he ate. The fourth type consist of cases where the subject "has a religious experience in having certain sensations private to himself, yet these are not of a kind describable by normal vocabulary."21 Swinburne does not provide concrete examples of what this might be like but perhaps that is due to the nature of these experiences; they are ineffable. The final type of religious experience consists of those in which the subject is aware of God and/or God's action not because of any particular sensation (physical or spiritual) but rather because "it just so seems to him, but not through his having sensations." ${ }^{22}$ This last type of experience is quite typical among Pentecostals, for example, when someone "senses" that God is directing them to pray for someone, speak a word of prophecy to another individual, or to provide for the needs of some in want. If asked, "what was it about your experience that made it seem to you that you were having an experience of God?" the subject will respond, "It just did. There was no visual, auditory, or any other sensations that made it seem thus to me."23

What unites these five types of experiences-besides the fact that they are purported experiences of God or of actions of God-is that they are all forms of perception; there is no act of inference or process of discernment occurring. ${ }^{24}$ Considering the first type of experience, the subject-Jonathan

20 Swinburne, The Existence of God, 299.

21 Swinburne, The Existence of God, 300.

22 Swinburne, The Existence of God, 300.

23 Swinburne, The Existence of God, 301. My description of a "typical" pentecostal experience should not be thought of as ruling out other experiences such as mental impressions, physiological impressions (such as a burning sensation), or having Scripture being brought to mind.

24 I take it that the experience of perception "involves the presentation of mind-independent objects to a subject, and such objects are experienced as present or there such that the character of experience is immediately responsive to the character of its objects." Tim Crane and Craig French, "The Problem of Perception," in The Stanford Encyclopedia of Philosophy (Spring 2017 Edition), ed. Edward N. Zalta, https://plato.stanford.edu/archives/spr2017/ entries/perception-problem/, accessed October 20, 2020. By inference I am referring to the process, roughly speaking, of coming to conclusions through the analysis of premises, in this case premises about perception. By discernment I refer, roughly, to the act of examining one's beliefs about perceptions and engaging in a process of weighing the propositions one holds about one's own perceptions. 
Edwards-does not see the sun, the moon, and the stars, and then reasons his way to a belief in God's wisdom and excellency. Rather, Edwards perceives these attributes of God upon perceiving these natural objects. ${ }^{25}$ Likewise, in the fifth type of experience, the subject - say, a college-aged charismatic Christianperceives that God is directing her to pray for her friend. She does not infer from some experience that God wants her to undertake this action; rather, she perceives God's direction to her.

\subsection{Perceiving Answered Prayers}

For our purposes the first and fifth types of spiritual perceptions are especially relevant. Consider once again the case of Mary praying for Peter. Mary prays for Peter to be healed, and after her prayer, Peter is no longer afflicted by the virus. In Davison's explanation of a situation such as this one, Mary prays, sees Peter's healthy state subsequent to her prayer, and infers that God must have healed Peter. Mary is aware that there are other possible explanations of why Peter no longer suffers from COVID-19, but because of the DDP she cannot affirm that God healed Peter. We should note that the DDP seems to apply to beliefs that are formed as a matter of inference or beliefs that are arrived at through a process of discernment. If Mary believes that Peter was healed by God, but she arrived at that belief through a process of inference, then-assuming DDP is correct-she ought to withhold belief that God in fact healed Peter. But this is not the only story that could be told about Mary's belief about Peter's healing. Perhaps Mary arrived at that belief through a spiritual perception. Perhaps Mary's situation is akin to Swinburne's first type of spiritual experience. Like someone who sees a natural wonder-such as El Capitan in Yosemite or the Grand Canyon-and perceives the object as God's handiwork, perhaps Mary sees the series of events - prayer for Peter, Peter's lack of the virus—as God's handiwork. Mary does not infer that God has healed Peter. She sees God's healing action by means of her spiritual senses (one akin to the physical sense of sight). Mary might have also had a second type of spiritual experience, one more akin to Swinburne's fifth kind. Recall Swinburne's description of this type of experience: the subject is aware of God and/or God's action not because of any particular sensation (physical or spiritual) but rather because "it just so

25 There is no doubt that Edwards draws conclusions from his perceptions, that is, engages in a process of inference. His sermons that highlight order and harmony of creation bears this out. However, Edwards often speaks of immediate impressions. These kinds of immediate impressions of harmony and divine workmanship are the kinds of perceptions I have in mind. 
seems to him, but not through his having sensations." 26 This awareness is a type of spiritual perception that occurs by means of some spiritual sense that we simply do not have a physical analogue for. When asked how she is aware of God's healing action, Mary will not appeal to any particular sensation; rather, she will explain that it just seems to her that God healed Peter. If Mary is accurately reporting her experience that it seems to her that God healed Peter, then, once again, DDP does not apply since Mary did not arrive at a belief that God answered her prayer by virtue of some inferential process. ${ }^{27}$ She is describing the content of her spiritual perception: she perceives that God healed Peter.

Let us assume that one of the previous two types of experiences accurately describes Mary's spiritual perception of God's healing Peter. Is she warranted in believing her perception? Or should she withhold belief about her perception? In the following section I address the epistemology of spiritual perceptions.

\subsection{Warranted Spiritual Perceptions}

In recent years a number of analytic philosophers have expressed interest in the epistemology of religious experiences. ${ }^{28}$ Caroline Franks Davis, for example, has argued that "[r]eligious incorporated interpretations, like all incorporated interpretations, must be regarded prima facie as probably trustworthy, but challenges are always possible." ${ }^{29}$ William Alston has made the claim that within the context of socially established practices, religious experiences are prima facie justified, provide we do not have sufficient reason to regard these experiences as unreliable. ${ }^{30}$ What is significant about Davis's and Alston's arguments is that they both operate with a notion of socially established practices

26 Swinburne, The Existence of God, 300.

27 I should note that there will be times when someone has a spiritual perception and then engages in the process of inference or discernment described in note 24 above. Yet, for the purposes of this argument, I am more concerned with perception prior to an inferential process or a discernment process.

28 Not all "religious feelings" are "religious experiences," neither are "mystical experiences" to be equated with "religious experiences." I accept Mark Webb's minimalist definition of a religious experience as "experiences that seem to the person having them to be of some objective reality and to have some religious import." Webb, "Religious Experience," in The Stanford Encyclopedia of Philosophy (Winter 2017), ed. Edward N. Zalta, https:// plato.stanford.edu/archives/win2o17/entries/religious-experience/, accessed October 20, 2020 .

29 Caroline F. Davis, The Evidential Force of Religious Experience (Oxford: Clarendon Press, 1989), 165 .

30 William P. Alston, Perceiving God:The Epistemology of Religious Experience (Ithaca: Cornell University Press, 1991), 225. 
and conceptual schemes regarding divine action. ${ }^{31}$ Swinburne's account, by contrast, does not address the doxastic context in which perception occurs; nevertheless, Swinburne's epistemology is still helpful.

Swinburne operates with a causal theory of perception. Drawing on P.F. Strawson's account of perception, Swinburne explains that " $S$ perceives $\mathrm{x}$ (believing that he is doing so) if and only if an experience of its seeming (epistemically) to $S$ that $x$ is present is caused by $x$ 's being present." ${ }^{32}$ Thus, if $S$ has a genuine experience of God, it is because God has in fact caused the perception. This conclusion is backed by the principle of credulity, according to which, "if it seems (epistemically) to a subject that $x$ is present (and has some characteristic), then probably $x$ is present (and has the characteristic)" 33 In other words, "what seems to us to be so probably is so." ${ }^{44}$ For example, if it seems to me that I am seeing a purple and gold Lakers jersey before me, then, in absence of counterevidence, there is probably a purple and gold Lakers jersey before me. This principle, Swinburne asserts, is a basic principle of rationality that ought to be accepted in the absence of special considerations. If we deny this principle, Swinburne argues, then total skepticism would follow. ${ }^{35}$

\subsection{Credulity and Answered Prayers}

What does the principle of credulity mean for our religious experiences? According to William Abraham, it follows that "we should take that awareness [of God] as veridical unless we have good reason to believe otherwise." ${ }^{36}$ In our cases involving prayer, then, we ought to say that if $\mathrm{S}$ prays for $\mathrm{E}$ to occur and $\mathrm{E}$ occurs and S perceived God answering the prayer for $\mathrm{E}$, then [according to the principle of credulity] $S$ is warranted in believing that God answered S's prayer, barring good reasons to believe otherwise. In the case of Mary, we ought to say that if she has a perception of God healing Peter as a result of her prayer, then she is warranted in believing that God answered her prayer. Contra Davison's claim, based on the principle of credulity, $\mathrm{S}$ need not withhold belief regarding whether or not God answered S's prayer. If S inferred from her perceptions that God answered her prayer, however, DDP would apply, and Davison would have

\footnotetext{
$31 \quad$ William J. Abraham, "Analytic Philosophers of Religion," in The Spiritual Senses: Perceiving God in Western Christianity, ed. Paul Gavrilyuk and Sarah Coakley (Cambridge: Cambridge University Press, 2012), 281, 283.

32 Swinburne, The Existence of God, 296.

33 Swinburne, The Existence of God, 303.

34 Richard Swinburne, Mind, Brain, and Free Will (Oxford: Oxford University Press, 2013), 42.

35 Swinburne, Mind, Brain, and Free Will, 43. See also Swinburne, The Existence of God, 306, where he claims that denying the principle of credulity lands us in a "sceptical bog."

36 Abraham, "Analytic Philosophers of Religion," 28o.
} 
grounds for arguing that $S$ ought to withhold belief. In the situations described above, however, $\mathrm{S}$ did not infer that God answered her prayer; she made a perceptual claim about God's action. Based on the principle of credulity, then, S's belief that God answered her prayer is warranted.

\subsection{Summary}

I have argued that, contra Davison, in some cases where $\mathrm{S}$ prayed for $\mathrm{E}$ and $\mathrm{E}$ occurred, S can be warranted in believing that God answered S's prayer for E. This was based on the application of the principle of credulity to the notion of spiritual senses/spiritual perception. In the following section I argue that given Christian teachings on the nature of petitionary prayer we have additional warrant for the belief that God answered S's prayer.

\section{3 "Enhancers" and the Theology of Prayer}

Just because the principle of credulity inclines us to believe that, in cases where S perceives God answering S's prayer for E, God actually answered that prayer, this does not mean that one ought always to believe that the perception is veridical. The principle of credulity includes the possibility of defeaters. So even though perceptual claims are basic and therefore warranted, there are ways to challenge the veridical nature of such experiences. If one can prove that there are strong positive reasons for the challenge, then what a person seems to perceive is probably not true. ${ }^{37}$ Paul Draper highlights a number of conditions that would serve as defeaters to a perceptual claim; for example, if the subject is unreliable, when the object is known not to exist, when background evidence makes it probable that the object was not present, or when we know that some object was not in fact the cause of the perception. ${ }^{38}$ Such defeaters provide evidence that the experience is not indicative of the truth of the situation. If defeaters like these are not present, then the perception ought to be taken as veridical.

If a defeater undercuts the warrant for believing that one's perception is veridical, then an enhancer provides further reasons for thinking that the perception accurately reflects reality. Draper speaks of two types of enhancers: corroborating enhancers and reinforcing enhancers. He explains:

\footnotetext{
37 Paul Draper, "God and Perceptual Evidence," International Journal for Philosophy of Religion 32 (1992): 152.

38 Draper, “God and Perceptual Evidence," 154-155.
} 
A corroborating enhancer is independent support for the perceptual claim in question. A reinforcing enhancer provides no independent support for the perceptual claim, but does provide support for the claim that the experience in question is indicative of the truth of the claim. ${ }^{39}$

As an example of a reinforcing enhancer consider the following situation. While on vacation in Los Angeles Alfred seems to see a Mexican Free-Tailed Bat-a bat that is quite common to Southern California and just so happens to smell like the Corona brand beer. ${ }^{40}$ Alfred claims to have seen Mexican FreeTailed bats in the past and his friend, Bruce, who is a chiropterologist (someone who studies bats), confirms that Alfred has correctly identified this kind of bat each time in the past. This reinforces the likelihood of Alfred's perception being correct because it decreases the antecedent probability of Alfred's perception being mistaken. Now suppose that Alfred seems to see a Mexican Free-Tailed Bat, but he also smells the distinctive beer-like smell that accompanies these bats. This would act as independent support that this kind of bat is actually present. It corroborates Alfred's purported perception.

I suggest that S's claim regarding her perception of God answering her prayer ought to be taken as being correct unless there are defeaters that undercut her claim to such a perception. Her claim ought to be considered even more probable if there are enhancers in place that provide support for the claim that the perception is indicative of reality.

\subsection{Theological Enhancers}

In a response to Alston's epistemology of religious experiences, Joshua Seigal explains that the prima facie warrant assigned to spiritual perceptions can be overridden by more firmly entrenched beliefs within a doxastic practice. ${ }^{41}$ If a perception does not conform to the tradition or is not in accordance with what God would be expected to do or say, and if the perception results in the reversal of spiritual development, then the warrant is undercut. ${ }^{42}$ If any of these criteria are present, then the prima facie warrant for believing the perception is overridden. These criteria serve as defeaters. But what if we considered the inverse of these defeaters? Doing so, we could develop a list of theological enhancers.

\footnotetext{
39 Draper, "God and Perceptual Evidence," 156.

40 Natural History Museum of Los Angeles, "Backyard Bats," https://nhm.org/community -science-nhm/backyard-bats, accessed October 20, 2020.

41 Joshua Seigal, "'God Told Me to Do It': Sceptical Theism and Perceiving God," in Religious Studies 48 (2012): 97.

42 William Alston, Perceiving God, 204.
} 
If, for instance, Mary's perception that God healed Peter conforms to the tradition's understanding of divine action, is in accordance with the type of action God would be expected to do, or results in Mary's spiritual development, then we would have further reason to suspect that Mary's perception is warranted. Let us take each criterion in turn.

\subsection{Tradition and Testimony}

In his discussion of defeaters, Alston says that we can discount perceptions that "represent God in ways that are incompatible with the main lines of tradition." ${ }^{43}$ If we seek an enhancer for the perception of an answered prayer we could appeal to instances in the Christian tradition that speak of God answering prayers. Such examples are not hard to find. After meeting with Ambrose, Monica famously prayed for Augustine's salvation. Augustine eventually came to the faith. Reflecting on his mother's piety, Augustine concluded that it was his mother's prayers that brought him to God. Consider scriptural examples. The Bible shows us Hannah's desperate prayer for a son (1Sam 1:10-11) and we are told that "in the course of time Hannah became pregnant and gave birth to a son. She named him Samuel, saying, 'Because I asked him of the Lord." In Acts "the church prayed fervently to God" for Peter who was in prison (Acts 12:5). Peter is set free by an angel and says to himself, "Now I am sure that the Lord has sent his angel and rescued me" (Acts 12:11). The author of Acts portrays this event as an answer to prayer. In 2 Kings 19 Hezekiah prays for God to deliver Jerusalem from the hands of the Assyrians. That night an angel of the Lord put to death 185,000 in the Assyrian camp. Again, the event is portrayed as an answer to prayer. Whether it be church tradition or the tradition embodied in Scripture, tradition testifies to the notion that God answers prayer.

The force of the tradition that God answers specific prayers is multiplied when one takes into account the testimony of contemporary believers regarding their perception of God answering prayers. Writing about testimony in the pentecostal tradition, Grant Wacker writes that "early Pentecostals assumed their personal faith stories bore normative implications for others." 44 This normative force of personal testimonies can easily be applied to the issue of answered prayer. If Pentecostals — and other Christians - bear witness to the fact that God answers prayer, then we can speak not only of a past tradition of God answering prayer but a contemporary tradition as well.

43 William Alston, Perceiving God, 237.

44 Grant Wacker, Heaven Below: Early Pentecostals and American Culture (Cambridge: Harvard University Press, 2001), 58. 
The attentive reader might be wondering; "Does the testimony of Christian tradition (and contemporary Christians) actually enhance the warrant of the person who prays perception?" After all, if one's perception of God answering a prayer could be unwarranted, then couldn't the perceptions of the great cloud of witnesses be unwarranted as well? If Mary's perception is unwarranted, and she should remain agnostic, then why shouldn't Augustine, Hannah, Peter, Hezekiah, and countless others do so as well? Recall, my argument is not that conformity to the Christian tradition - that God answers prayerprovides warrant, rather, it is that conformity to the tradition enhances the probability of the perception being warranted. There is a multiplicity of views regarding the function of testimony's relation to knowledge. Some consider testimony to be a basic source of knowledge and others believe that testimony transmits knowledge from one person to another. ${ }^{45}$ Regardless of this relation, it is not unheard of to think of testimony carrying a default kind of justification. ${ }^{46}$ But even if this is wrong, and testimony does not confer warrant to the belief that God answered a specific prayer, it serves to enhance the probability of a belief that is already warranted on the grounds of the principle of credulity. Thus, the Christian tradition and contemporary testimony serve as corroborating enhancers.

\subsection{Accordance with What God Would Be Expected to Do}

If a spiritual perception is not in accordance with what God would be expected to do or say, then the veracity of the spiritual perception would be defeated. However, if the perception of some answered prayer, E, is in accordance with what God would be expected to do, then the probability of the perception being true is enhanced. Can we form expectations about what kind of prayers God would be expected to answer? Scripture indicates that we can. In his account of the biblical theology of prayer J. Gary Millar writes that there are "'no brainer' prayers we should pray for as individuals and communities because God has already guaranteed to answer."47 We can be confident that God will answer these prayers because God himself has said he will keep his covenant promises. What are these prayers? Millar lists five:

45 John Greco, "Recent Work on Testimonial Knowledge," American Philosophical Quarterly 49 (2012): 15 .

46 Robert Audi, "The Place of Testimony in the Fabric of Knowledge and Justification," American Philosophical Quarterly 34 (1997): 409.

47 J. Gary Millar, Calling on the Name of the Lord: A Biblical Theology of Prayer (Downers Grove: InterVarsity Press, 2016), 239. 
1. Prayer for forgiveness (1John 1:9)

2. Prayer to know God better (Eph 1:15-22; 3:18-19)

3. $\quad$ Prayer for wisdom (Jas 1:5-6)

4. Prayer for strength to obey/love/live for God (Eph 1:15-22; 3:14-15)

5. Prayer for the spread of the gospel (Luke 10:2; Acts 5 ; $\left.\mathrm{Col}_{4}\right)^{48}$

If one prays for any of these things, and these things come about, then we can be confident that God has responded to one's prayers. These types of prayers, however, are not the focus of our study. We are concerned with prayers for such things as healing, a job, vocational direction, and so forth. In other words, requests that God has not promised to grant. ${ }^{49}$ Can we still form expectations about what kinds of things God would answer prayers for even though we cannot guarantee that he will answer those prayers each time? Scripture indicates that we can.

For example, Scripture indicates that God answers prayers that are in accordance with his will. To be in tune with his will, in part, requires that the person praying have certain spiritual characteristics. As Stanley Grenz points out, "Spirituality leads to effective praying, whereas the prayer of the unspiritual person is of no avail." ${ }^{50}$ Having a heart of unforgiveness hinders prayer (Matt 6:12). Unresolved interpersonal conflicts with other believers can hinder the effectiveness of prayer, as can a lack of compassion toward the poor (Prov 21:13).

Besides the spiritual state of the person praying, a person's motivation comes in to play as well. As James says, "You ask and do not receive, because you ask wrongly, in order to spend what you get on your pleasures" (Jas 4:3). Moreover, Grenz indicates that "petitioning God while being unwilling to get involvedis ultimately ineffective. Prayer must be accompanied by cooperation, by a willingness to be engaged in the process of answering our requests." 51 These

$48 \quad$ Millar, Calling on the Name of the Lord, 239.

49 The fact that God has not promised to answer certain kinds of prayers should not be seen as a contradiction to Jesus's statement in John 14:13, "I will do whatever you ask in my name, so that the Father may be glorified in the Son," and in similar statements. See, for example, David Crump's explanation of these seemingly unconditional statements regarding responses to petitionary prayers. He explains, "Jesus specified the precise content of the prayers about which he offered that guarantee. He did not promise a positive to response to any and every personal request but only to those that aimed at following his ministry of bringing glory to God." David Crump, Knocking on Heaven's Door: A New Testament Theology of Petitionary Prayer (Grand Rapids: Baker, 2006), 161.

50 Stanley Grenz, Prayer: The Cry for the Kingdom, rev. ed. (Grand Rapids: Eerdmans, 2005), 55 .

$51 \quad$ Grenz, Prayer, 62. 
various points go to show that our spiritual condition and effective prayers go hand in hand.

If God has indicated that he will tend not to answer prayers that arise from persons making requests who display the previously mentioned characteristics, we reasonably conjecture that if S prayed for $\mathrm{E}$, but $\mathrm{S}$ displayed the negative characteristics mentioned above, then E came about not because God answered S's prayer but for some other reason. Vice versa, we could conjecture that if $S$ prayed for $E$, but $S$ displayed the inverse of these negative characteristics and E came about, God answered that prayer. Of course, this observation is grounded in the nature of relationships. People tend to act in ways that are characteristic of themselves. Consider the following example. Dexter asks his friend Ed to buy him a burger. Ed walks away. Five minutes later, someone walks up to Dexter and says to him, "here is your burger." What explains the appearance of a burger? Well the burger could have been purchased for Dexter by some other person, the burger could have been purchased for some other person and incorrectly delivered to Dexter, or Ed could have purchased the burger and had it sent to him. Might it be the case that knowing Ed's character as a promise keeper, and knowing that in the past Ed had promised always to buy burgers when asked, gives a strong reason to think that Dexter's belief that Ed bought the burger is correct? If one grants this in such an ordinary case, might it not also be the case that knowing God's character and his tendency to answer specific types of prayers then act as a corroborating enhancer for believing that one's perception that God answered one's prayer is correct?

\subsection{Spiritual Development}

According to Alston, if a spiritual perception results in the reversal of spiritual development, then the warrant for that perception being veridical is undercut. ${ }^{52}$ I suggest that if the purported perception results in spiritual growth, then the probability of the perception being true is enhanced.

In Institutes 3.20.3 Calvin explains the various spiritual benefits accorded to us when we realize that God has answered our petitionary prayers. He explains that those who pray petitionary prayers are "fired up with a zealous and burning desire to seek, love and serve God." ${ }^{3}$ Thus, their prayers have a sanctifying effect. Receiving answered prayers grows their heart of gratitude and thanksgiving. Moreover, "having obtained what we were seeking and being convinced

\footnotetext{
$5^{2}$ William Alston, Perceiving God, 204.

53 John Calvin, Institutes of the Christian Religion, ed. John T. McNeill, trans. Ford Lewis Battles, 2 vols., Library of Christian Classics (Louisville, KY: Westminster John Knox Press, 1960), 3.20.3.
} 
that he answered our prayers, we should be led to meditate upon his kindness more ardently." ${ }^{54}$ Prayer leads believers to appreciate the things they have because they realize they have not coincidentally acquired such things; rather, God himself has heard and granted their requests. Finally, Calvin reminds believers that answered prayers serve to confirm their finitude and God's providence. ${ }^{55}$ He explains that when they pray, "use and experience may, according to the measure of our feebleness, confirm his providence, while we understand not only that he promises never to fail us, and of his own will opens the way to call upon him at the very point of necessity, but that he ever extends his hand to help his own, not wet-nursing them with words but defending them with present help." ${ }^{56} \mathrm{God}$, on this account, uses one's perception of answered petitionary prayers to spark spiritual growth in the believer. If, as Calvin seems to indicate, this is one of the primary functions of prayer, then it is reasonable to believe that God would ensure that believers accurately perceive his action. God, by my lights, would not want believers to miss the fact that he answered their prayer and attribute that answer to coincidence because this would not lead to the spiritual growth that he desires for them. Additionally, God, being concerned with truth, would not want actions that were not actually his to be attributed to him. Thus, it seems to be in God's interest to ensure that, in typical situations, believers have accurate perceptions regarding petitionary prayers. Assuming that God - typically—would ensure accurate perception of answered prayers, then we can assume that when some person claims to have a perception of an answered prayer and that the perception leads to spiritual growth, then the probability of the perception being veridical is enhanced.

\subsection{Summary}

Mary prayed for Peter to be healed; after her prayer, Peter recovers from his ailment. Is her belief that God answered her prayer warranted? I have suggested that if her belief that God answered her prayer is a description of her perception, then, given the principle of credulity, Mary is warranted in her belief. If Mary claims to perceive-via spiritual perception-that God answered her prayer, but if Mary is unreliable, if God is known not to exist, if background evidence makes it probable that the God was not present, if we know for a fact

54 Calvin, Institutes, 3.20.3.

55 On humanity's finitude and dependence in Calvin, see Michael Parsons, "John Calvin on the Strength of Our Weak Praying," Evangelical Review of Theology 36 (2012): 55-58, and Julie Canlis, Calvin's Ladder: A Spiritual Theology of Ascent and Ascension (Grand Rapids: Eerdmans, 2010), 63-65.

$5^{6}$ Calvin, Institutes, 3.20.3. 
that the object perceived was not, in fact, the cause of the perception, if the perception does not conform to the Christian tradition or is not in accordance with what God would be expected to do, or if the perception results in the reversal of spiritual development, then the warrant for her perception is undercut. I suggested, however, that if none of these defeaters are present, and if the perception conforms to the Christian tradition, is in accordance with what God would be expected to do, or results in her own spiritual growth, then the warrant for Mary's perception is enhanced. Thus, Mary — and others in situations like hers-need not remain agnostic about whether God answered her prayer. Mary - contra Davison - can confidently say that God answered her prayer because her perception is warranted.

\section{4}

\section{Coda-Pastoral Implications}

My burden in this essay has been to demonstrate, contra Davison, that one can be warranted in believing that God has responded to one's specific petitionary prayers. To do so I have drawn upon Richard Swinburne's epistemology of spiritual perceptions. Although at first glance discussions of warrant, defeaters, enhancers, or philosophy of perception might seem far removed from the spiritual lives of ordinary believers, this could not be further from the truth. Being able to claim confidently that God has answered one's prayer is crucial to the Christian life. No only does it reinforce the fact that God cares for the person who prays, it also gives them further reason to glorify God. Moreover, being able to testify confidently about God's response to prayer has evangelistic implications. How often have people been moved closer to faith in Christ by hearing a testimony of God's action in the world? How often has someone put their faith in Christ after having a prayer answered? Arguably, undermining the notion that we can be confident that God answered our prayers would end up undermining critical aspects of the Christian life, namely, the relational and missiological aspects of the spiritual life. 